\title{
Pendampingan Optimalisasi Fungsi Perpustakaan Untuk Menumbuhkan Budaya Baca dan Meningkatkan Kemampuan Literasi Siswa Sekolah Dasar Di Kota Parepare
}

\author{
Wawan Krismanto \\ Prodi PGSD Fakultas Ilmu Pendidikan Universitas Negeri Makassar \\ wawan.krismanto@unm.ac.id
}

\begin{abstract}
ABSTRAK
Berdasarkan hasil studi tentang kemampuan literasi, analisis situasi dan kondisi empiris perpustakaan di berbagai sekolah dasar di Kota Parepare, maka dapat disimpulkan bahwa permasalahan yang dihadapi oleh mayoritas sekolah dasar terkait dengan fungsi perpustakaan untuk menumbuhkan budaya baca dan kemampuan literasi siswa adalah: 1) tata kelola perpustakaan yang masih rendah, 2) kompetensi sumber daya manusia pengelola perpustakaan yang masih rendah dan 3) program pemanfaatan perpustakaan di sekolah dasar untuk menumbuhkan budaya baca dan kemampuan literasi siswa yang masih rendah pula. Program pengabdian ini berusaha memberikan solusi untuk mengatasi permasalahan mitra berupa pendampingan optimalisasi fungsi perpustakaan. Pendampingan melibatkan pelaksana pengabdian, dosen pengampu dan mahasiswa mata kuliah Pengelolaan Perpustakaan di SD, kepala sekolah, guru-guru, para staf dan siswa-siswi di 6 sekolah mitra. Tahapan pendampingan adalah menata ulang tata kelola perpustakaan baik administrasi maupun tata kelola ruangan dan koleksi, peningkatan kemampuan SDM pengelola perpustakaan dan pengembangan program perpustakaan untuk menumbuhkan budaya baca dan kemampuan literasi siswa. Berdasarkan hasil pendampingan, maka dapat disimpulkan bahwa pendampingan telah berhasil mengembalikan fungsi perpustakaan sebagai pusat kegiatan literasi di sekolah dasar. Tata kelola administrasi dan tata ruang beserta kolekasinya mampu menjadikan perpustakaan di 6 sekolah mitra sebagai tempat yang menarik dan menyenagkan untuk kegiatan literasi siswa. Fasilitas dan programprogram untuk menumbuhkan budaya baca dan kemampuan litrasi siswa juga telah tebentuk dan dilaksanakan di 6 sekolah mitra.
\end{abstract}

Kata Kunci: perpustakaan sekolah, kemampuan literasi, budaya baca

\section{PENDAHULUAN}

Salah satu persoalan mendasar yang dihadapi bangsa Indonesia setelah merdeka selama 72 tahun adalah persoalan literasi warga negaranya. Menteri Pendidikan dan Kebudayaan Muhajir Efendi pun mengakuinya bahwa "Kemampuan literasi kita jauh tertinggal dengan negara lain. Oleh karena itu, harus kita kejar agar tidak tertinggal lebih jauh lagi"(Kompas, 22/03/2017). Selain itu berbagai data survei juga menunjukkan hal tersebut. Studi tentang World's Most Literate Nations oleh Central Connecticut State Univesity yang dipublikasikan pada 9 Maret 2016 begitu menyentak bangsa Indonesia, sebab data menunjukkan Indonesia hanya menduduki urutan ke 60 dari 61 negara yang disurvei dalam hal literasi (CCSU, 2016)

Persoalan rendahnya literasi berkaitan erat dengan rendahnya budaya membaca. Membaca dalam hal ini tidak diartikan sempit sebagai pandai membaca. Kesalahan mendasar pada kalangan masyarakat adalah jika anak, katakanlah siswa sekolah dasar, dikatakan sudah mahir membaca saat ia lancar merangkai huruf menjadi kata, merangkai kata demi kata sampai ia menyelesaikan paragraf sebuah wacana. Sedangkan lanjutan dari kemampuan untuk memahami isi, memaknai isi dan kreativitasnya dalam mengungkapkan kembali isi bacaan baik secara lisan maupun tulisan sering terabaikan. Maka wajar berbagai survei tentang kemampuan membaca siswa Indonesia masih tergolong rendah. Survei Programme for International Students Assessment (PISA) yang dilakukan Organisation for Economic Co-operation and Development (OECD) tahun 2015 menunjukkan rata-rata skor kemampuan membaca siswa Indonesia masih dikisaran 397, masih dibawah rata-rata 72 negara yang disurvei yaitu 493 dan masih dibawah pula diantara negara ASEAN lain seperti Singapura (535), Vietnam (487) dan Thailand (409) (OECD, 2016).

Untuk membentuk budaya membaca sesuai dengan konsep literasi, maka diperlukan 
sebuah proses yang tidak sederhana. Menurut Sutarno (2003) budaya membaca terbentuk dari sebuah proses yang melibatkan setidaknya tiga hal yaitu minat membaca, kegemaran membaca dan kebiasaan membaca. Menyadari hal tersebut, Kementerian Pendidikan dan Kebudayaan telah berupaya dengan membuat kebijakan terkait dengan budaya membaca. Kebijakan tersebut diantaranya adalah Peraturan Menteri Pendidikan dan Kebudayaan Nomor 21 Tahun 2015 tentang Penumbuhan Budi Pekerti, salah satunya, mengenai kegiatan membaca buku nonpelajaran selama lima belas menit sebelum waktu belajar dimulai. Kegiatan tersebut adalah upaya menumbuhkan kecintaan membaca kepada peserta didik dan pengalaman belajar yang menyenangkan sekaligus merangsang imajinasi. Sebagai turunan peraturan menteri tersebut telah di sosialisasikan pula pada seluruh sekolah di Indonesia tentang Gerakan Literasi Sekolah, meliputi 3 tahapan yakni: 1) penumbuhan minat baca, 2) meningkatkan kemampuan literasi buku pengayaan dan 3) meningkatkan kemampuan literasi buku pelajaran (Kemdikbud, 2016).

Namun demikian, berdasarkan survei yang dilakukan oleh penulis di awal 2017, dari 24 sekolah dasar yang disurvei di Kota Parepare, hanya 33\% yang rutin melaksanakan sesuai dengan panduan gerakan literasi sekolah. Bahkan masih terdapat 33\% sekolah yang belum pernah melakukan program implementasi gerakan literasi sekolah sesuai panduan dan selebihnya pernah melaksanakan namun tidak rutin (Krismanto, 2017). Persoalan implementasi gerakan literasi sekolah sesungguhnya tidak hanya berhenti pada dilaksanakan atau tidaknya panduan dari kementerian tersebut. Namun terdapat persoalan mendasar lainnya terkait implementasi gerakan tersebut, yakni pengelolaan perpustakaan di sekolah dasar yang masih seadanya.

Merujuk pada Buku Panduan Gerakan Literasi Sekolah, maka yang menjadi titik sentral kegiatan gerakan literasi sekolah seharusnya adalah Perpustakaan Sekolah. Pertanyaannya, bagaimana keberadaan perpustakaan di sekolah dasar saat ini? Hal ini dapat dilihar dari 4 sisi yang sama pentingnya yakni sisi: 1) fasilitas, 2) administrasi pengelolaannya, 3) sumber daya manusia pengelolanya dan 4) program-program pemanfaatan perpustakaan untuk mendukung gerakan literasi sekolah. Berdasarkan data hasil survei yang dilakukan penulis, hanya sisi fasilitaslah yang berada dalam kategori baik, dalam arti memiliki standar gedung tersendiri, koleksi lebih dari 500 buku, fasilitas rak buku tersedia, ada petugas perpustkaan (meskipun merangkap guru) dan ada penambahan koleksi setiap tahun (Krismanto, 2017). Sementara tata kelola perpustakaan, sumber daya manusia pengelolanya dan ketersediaan programprogram pemanfaatan perpustakaan untuk mendukung gerakan literasi sekolah masih berkategori kurang baik (Krismanto, 2017). Inilah yang menjadi problem bagi sebagian besar perpustakaan di sekolah dasar dalam implementasi gerakan literasi sekolah saat ini. Sehingga pada akhirnya peningkatan budaya membaca siswa sekolah dasar belum maksimal sesuai yang diharapkan.

Berdasarkan analisis situasi dan kondisi empiris yang telah dipaparkan pada latar belakang di atas maka dapat disimpulkan bahwa permasalahan pada mitra pengabdian ini adalah: 1) tata kelola perpustakaan yang masih rendah, 2) kompetensi sumber daya manusia pengelola perpustakaan yang masih rendah dan 3) pemberdayaan program pemanfaatan perpustakaan di sekolah dasar yang masih minim.

Solusi yang ditawarkan untuk mengatasi permasalahan mitra adalah pendampingan optimaliasasi fungsi perpustakaan yang berisi program-program untuk memberikan solusi pada persoalan mendasar tentang: 1) tata kelola perpustakaan, 2) peningkatan kompetensi sumber daya manusia pengelolanya dan 3) pemberdayaan program pemanfaatan perpustakaan di sekolah dasar. Tiga program tersebut diharapkan akan menumbuhkan minat siswa untuk datang, senang dan nyaman berada di perpustakaan. Setelah minat tumbuh diharapkan akan meningkatkan motivasi siswa untuk membaca koleksi perpustakaan. Melalui penyusunan program pemanfaatan perpustkaan di sekolah akan memberi kesempatan siswa untuk melakukan berbagai aktivitas guna meningkatkan kemampuan literasi mereka. Pada akhirnya semua itu akan meningkatkan budaya membaca siswa dan kemampuan literasi siswa. Model sederhana dari proyek tersebut dapat dilihat pada bagan berikut.

\begin{tabular}{ll}
\hline \multicolumn{3}{c|}{ METODE KEGIATAN } \\
\hline \multicolumn{1}{c}{ Secara } & umum pelaksanaan \\
pendampingan & secara intensif dilakukan \\
dengan tahapan yang dapat dijelaskan pada \\
bagan berikut:
\end{tabular}




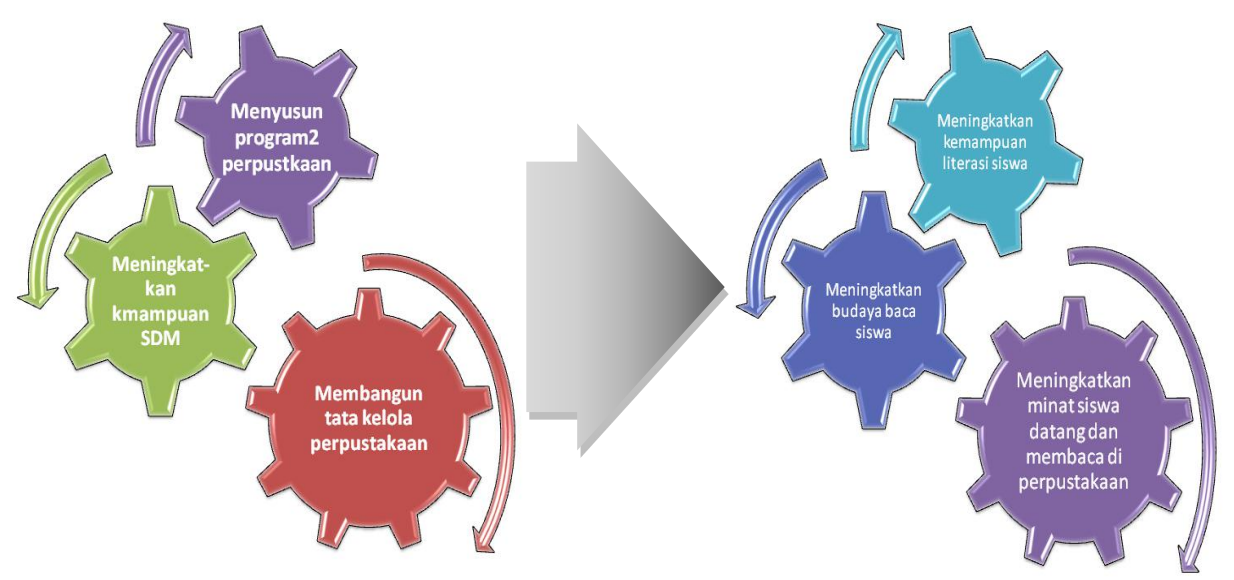

Gambar 1. Model Pendampingan Optimalisai Fungsi Perpustakaan di Sekolah Dasar

Selain melibatkan dosen, program ini melibatkan para mahasiswa peserta mata kuliah Pengelolaan Perpustakaan di SD pada semester genap tahun ajaran 2016/2017. Sebanyak 37 mahasiswa akan disebar ke 6 sekolah mitra yang telah ditentukan yaitu SDN 85, 89, 45, 79, 67 dan SD Muhammadiyah 01 Kota Parepare. Dosen pelaksana yang terdiri dari 3 orang melaksanakan pendampingan masing-masing di 2 sekolah.

\section{HASIL \& PEMBAHASAN}

Program pengabdian pendampingan optimalisasi fungsi

atau perpustakaan sekolah dasar ini mu;ai dilaksanakan pada awal April 2017. Penampingan bersama tersebut dilaksanakan dengan terlebih dahulu berkoordinasi dengan kepala sekolah, guru dan staf sekolah yang menjadi mitra pengabdian. Konsep pelaksanaan program ini adalah pemberdayaan, sehingga semua unsur yang ada pada sekolah sasaran proyek harus berdaya guna dan terlibat aktif bekerja mensukseskan program mulai dari kepala sekolah, para guru, staf sekolah dan para siswa.

Sasaran program yang diimplementasikan pada minggu pertama proyek adalah membenahi tata kelola perpustakaan meliputi tata administrasi terdiri dari buku induk koleksi, buku inventaris, buku anggota, buku peminjaman, buku pengunjung, kartu buku, kartu anggota dan sebagainya. Semua kelengkapan administrasi tersebut mayoritas tidak dikelola dengan baik, bahkan sebagian perpustakaan sekolah sasaran tidak memiliki. Berikut beberapa hasil produk pendampingan di minggu pertama.
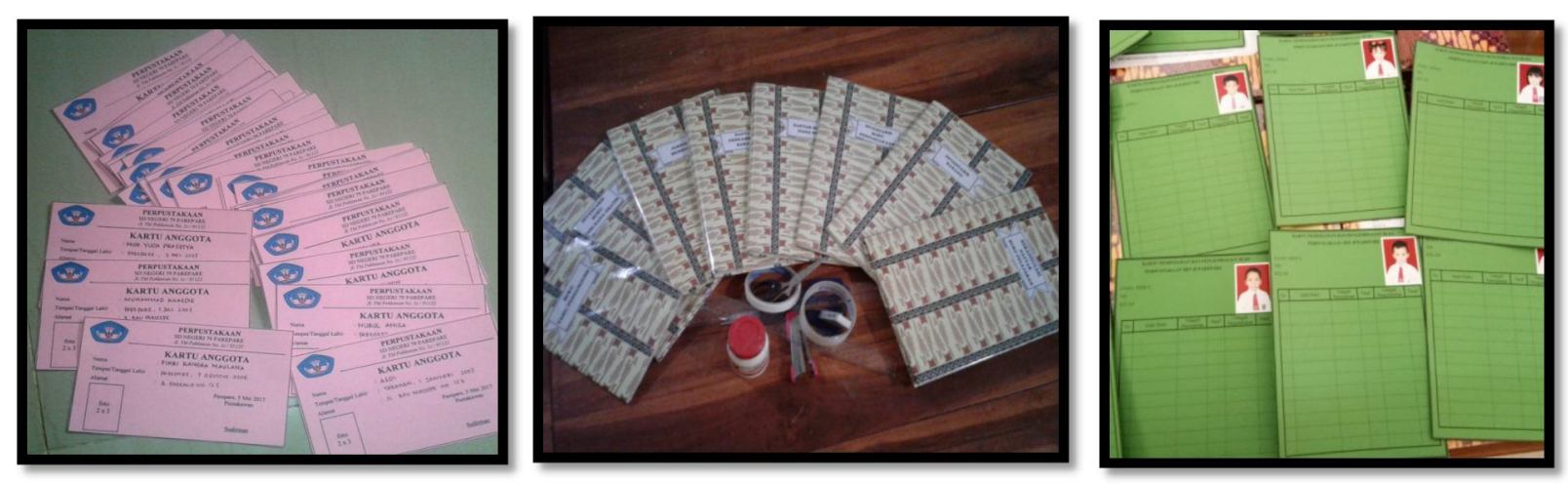

Berbagai buku administrasi pengelolaan Perpustakaan dan berbagai kartu di perpustakaan SDN 79, Muhamadiyah 1 dan SDN 45 Kota Parepare hasil pendampingan

Pada minggu kedua, proyek merambah pada pembenahan tata ruang dan tata letak koleksi buku. Mayoritas di 6 sekolah sasaran kondisinya memprihatinkan, bahkan sebagian nyaris seperti gudang. Kondisi ini tentu saja membuat siswa malas berkunjung ke perpustakaan, apalagi berlama-lama berada di perpustakaan. Penataan rak buku, dekorasi ruangan dan dinding juga nampak apa adanya. Demikian pula tata letak buku di rak-rak yang disusun secara monoton dan tidak ada klasifikasi sama sekali, hal tersebut 
menyulitkan siswa untuk mencari dan memilih buku-buku yang ingin dibaca. Pemilihan rakrak buku yang tidak tepat sesuai usia anak

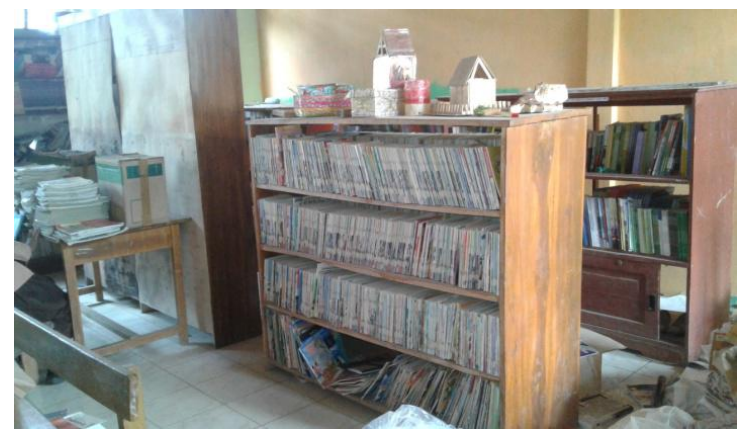

Kondisi Ruang Perpustakaan di SDN 85 Kota Parepare sebelum ada pendampingan
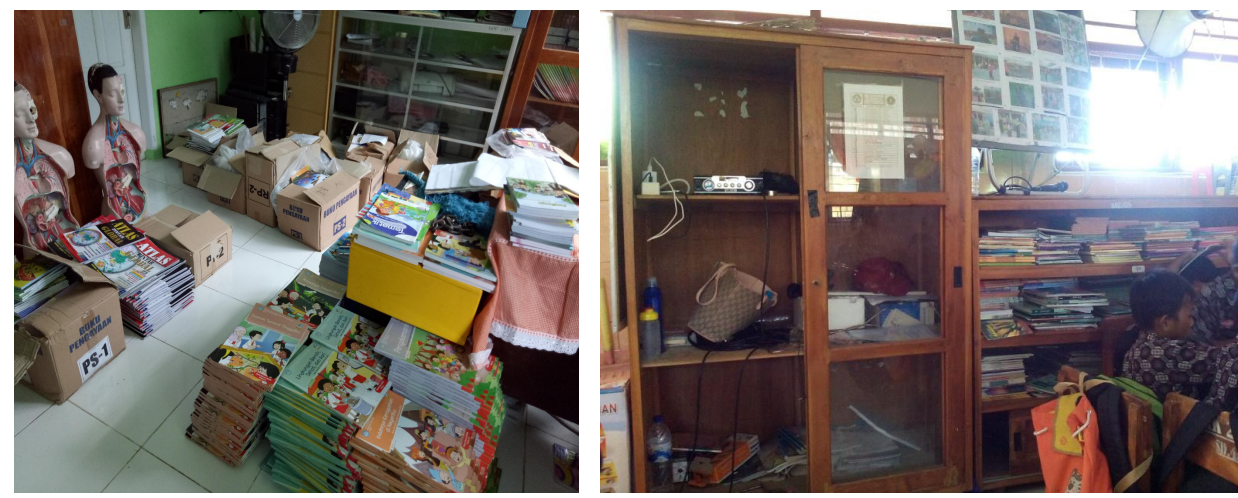

Kondisi Ruang Perpustakaan di SDN 79, 45 dan Muhamadiyah 1 Kota Parepare sebelum ada pendampingan

Setelah berjalan selama dua pekan, maka program pendampingan mewujudkan berbagai perubahan pada tata ruang dan koleksi perpustakaan. Dimulai dengan mempercantik ruang perpustakaan, membuat klasifikasi koleksi, menata rak dan menata ruang baca. Program ini merupakan langkah sekolah dasar juga menyulitkan siswa untuk menjangkau buku. Beberapa kondisi tersebut dapat dilihat pada gambar berikut:

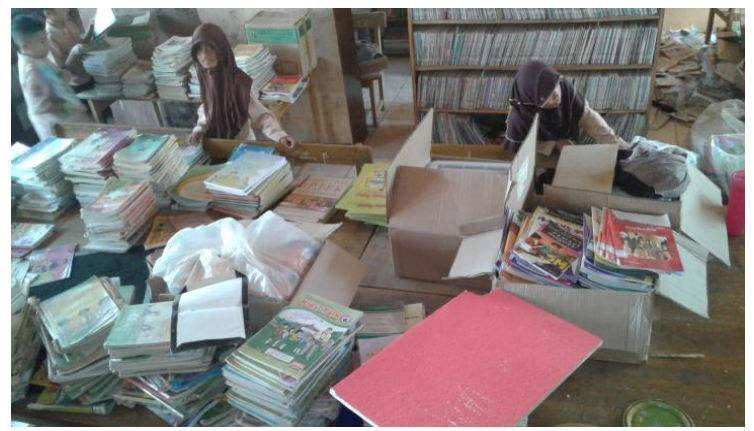




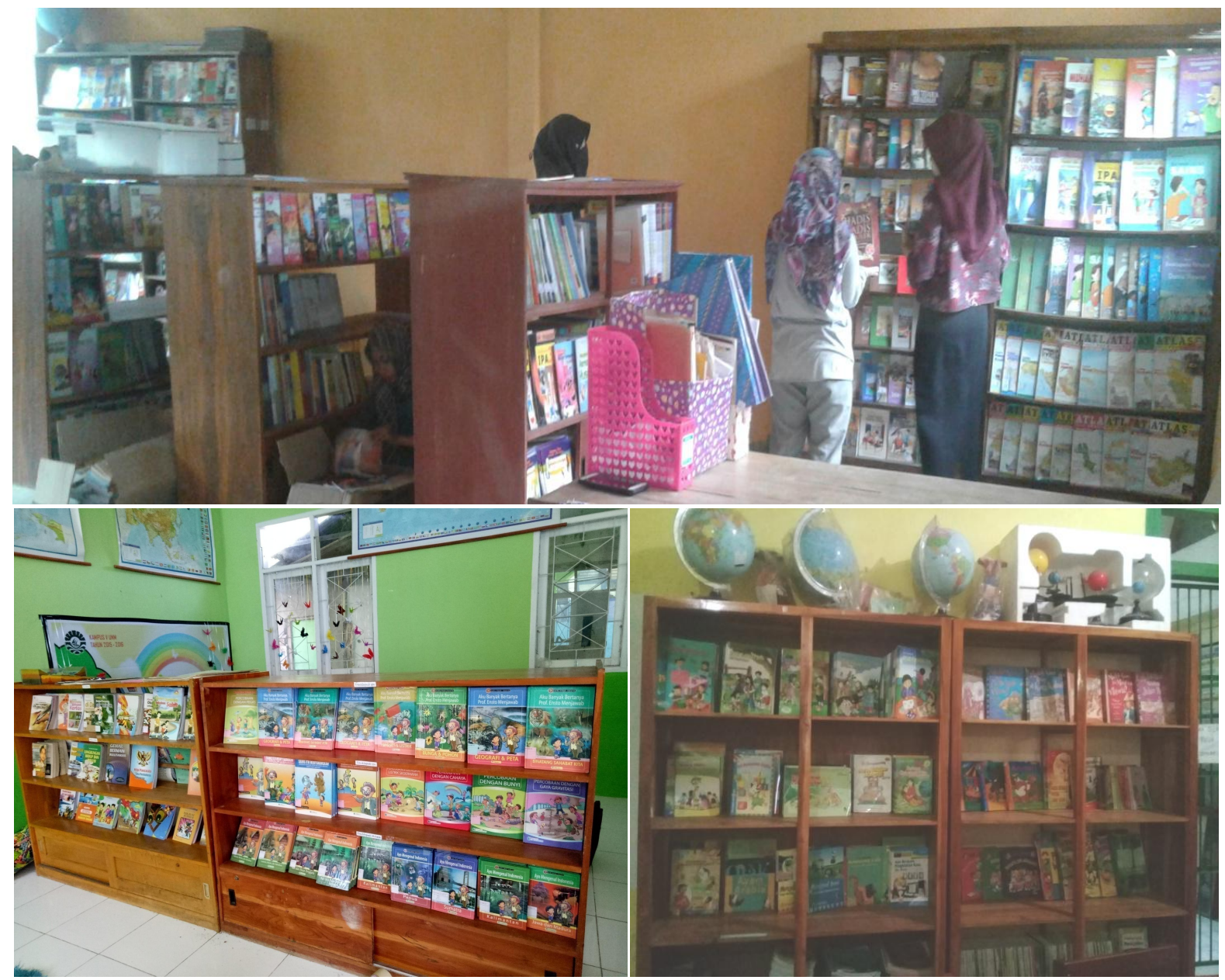

Program menata ulang penyusunan rak buku di SDN 85, 79 dan SD Muhammadiyah 01 Kota Parepare. Selain mengelompokkan berdasarkan Sistem Klasifikasi, arah buku diubah susunannya dengan cover menghadap ke muka, dengan demikian akan menarik siswa untuk melihat dan penasaran untuk membacanya.

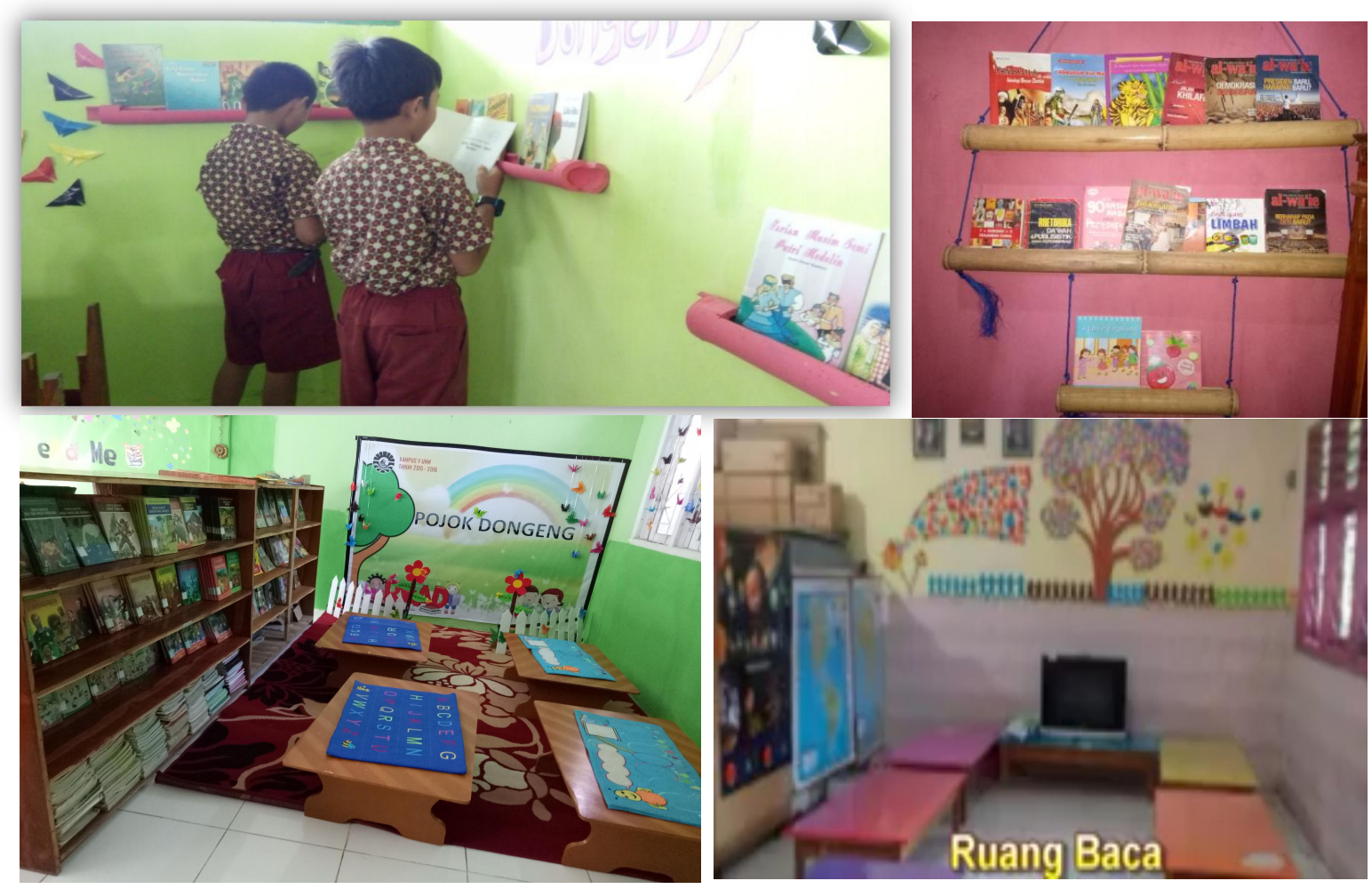

Selain menata ulang rak buku agar tampak menarik dan mudah dijangkau siswa, program pendampingan berusaha membuat rak-rak tambahan untuk buku-buku favorit dan menata ruang baca di SDN 79, Muhamadiyah 1 dan SDN 85 
Selain itu, pendampingan ini juga berusaha membuat fasilitas sederhana dari bahan-bahan yang juga sederhana (termasuk limbah kardus) untuk pojok baca dan pojok dongeng. Beberapa dibuat di dalam ruang perpusatkaan dan beberapa dibuat di luar perpustakaan. Diharapkan fasilitas ini mampu dimanfaatkan untuk program-program implementasi gerakan literasi sekolah yang bervariasi selain membaca 15 menit sebelum pembelajaran di kelas di mulai. Berikut beberapa fasilitas yang berhasil dikembangkan di sekolah mitra saat pelaksanaan pendampingan:

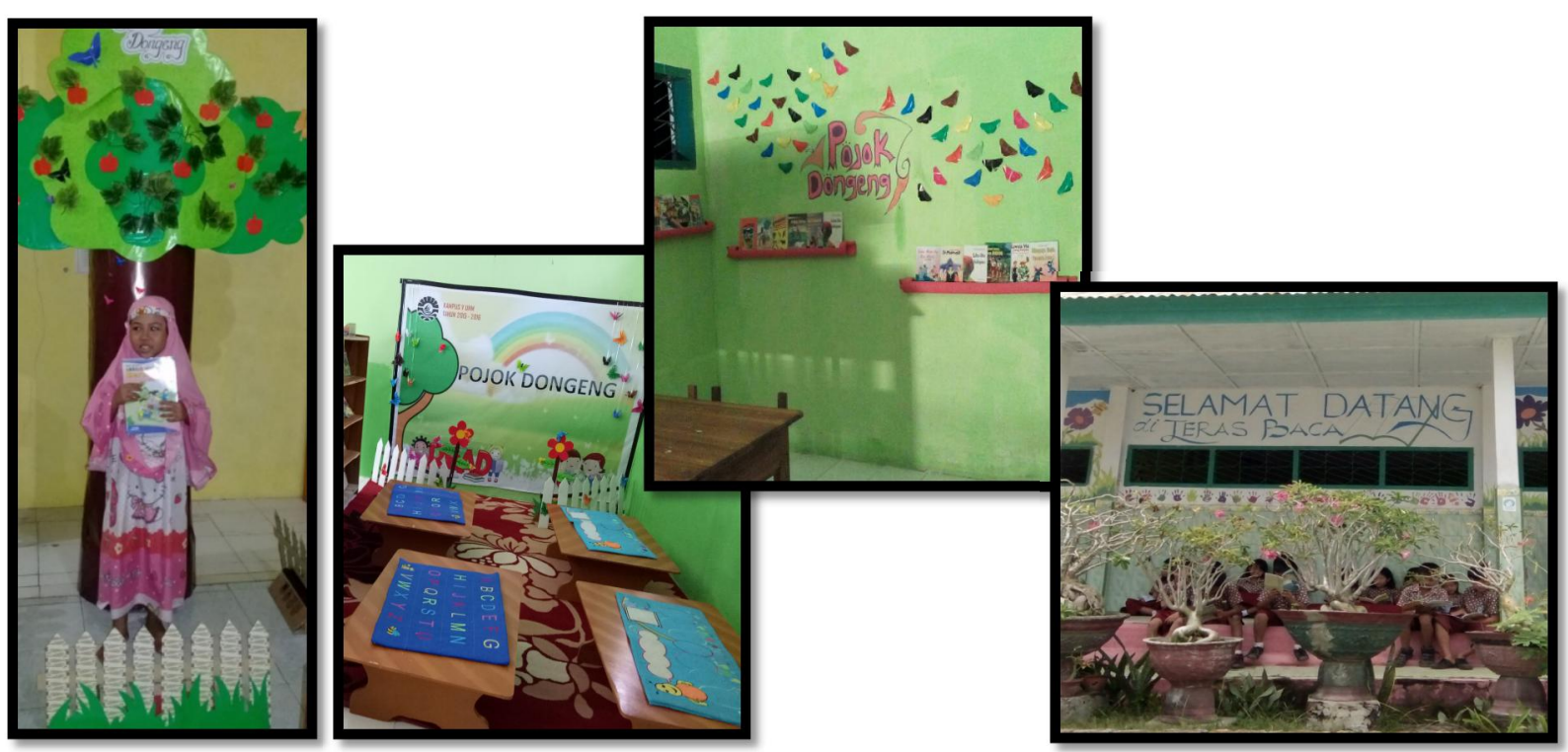

Beberapa fasilitas tempat membaca dan mendongeng di SD Muhamadiyah 01, SDN 85, 67, 89 dan 79 Kota Parepare yang berhasil dikembangkan saat penampingan

Setelah tata kelola administrasi perpustakaan sudah baik, tata ruang dan rak buku koleksi perpustakaan tampak menarik dan nyaman untuk kegiatan membaca siswa, maka di minggu keempat dan kelima, kegiatan pendampingan bergerak untuk mengimplementasikan program-program pemanfaatan perpustakaan untuk mendukung gerakan literasi sekolah. Program ini dilaksanakan untuk memacu siswa sekolah dasar untuk semakin termotivasi membaca dan merasa tertantang melalui berbagai kegiatan. Beberapa sekolah membuat kegiatan bercerita atau mendongeng sekali seminggu untuk masing-masing kelas. Kegiatan dilakukan secara bergiliran baik kelas maupun siswanya. Sebagian lainnya membuat program membaca bersama dalam hari tertentu, lalu siswa menyusun rangkuman hasil bacaan baik lisan maupun tulisan. Jika program ini rutin dilakukan maka akan membiasakan siswa untuk terlibat dalam kegiatan membaca.

Sesuai konsep literasi, maka siswa tidak hanya rutin membaca, namun mereka diberikan kesempatan untuk mengekspresikan informasi yang didapatkan dari aktivitas membacanya, seperti bercerita, mendongeng dan menulis. Kegiatan inilah yang diharapkan akan meningkatkan kemampuan literasi siswa. Dengan program-program seperti ini pula akan membuat implementasi gerakan literasi sekolah menjadi beragam dan tidak monoton pada kegiatan membaca 15 menit sebelum pelajaran dimulai. Secara langsung programprogram tersebut jelas mendukung 3 tahapan program Kementerian Pendidikan \& Kebudayaan yang disosialisasikan melalui Buku Panduan Gerakan Literasi di Sekolah Dasar, yaitu menumbuhkan minat membaca, meningkatkan kemampuan literasi buku pengayaan dan meningkatkan kemampuan literasi buku pembelajaran. Berikut beberapa kegiatan yang dilakukan di sekolah mitra saat penampingan. 

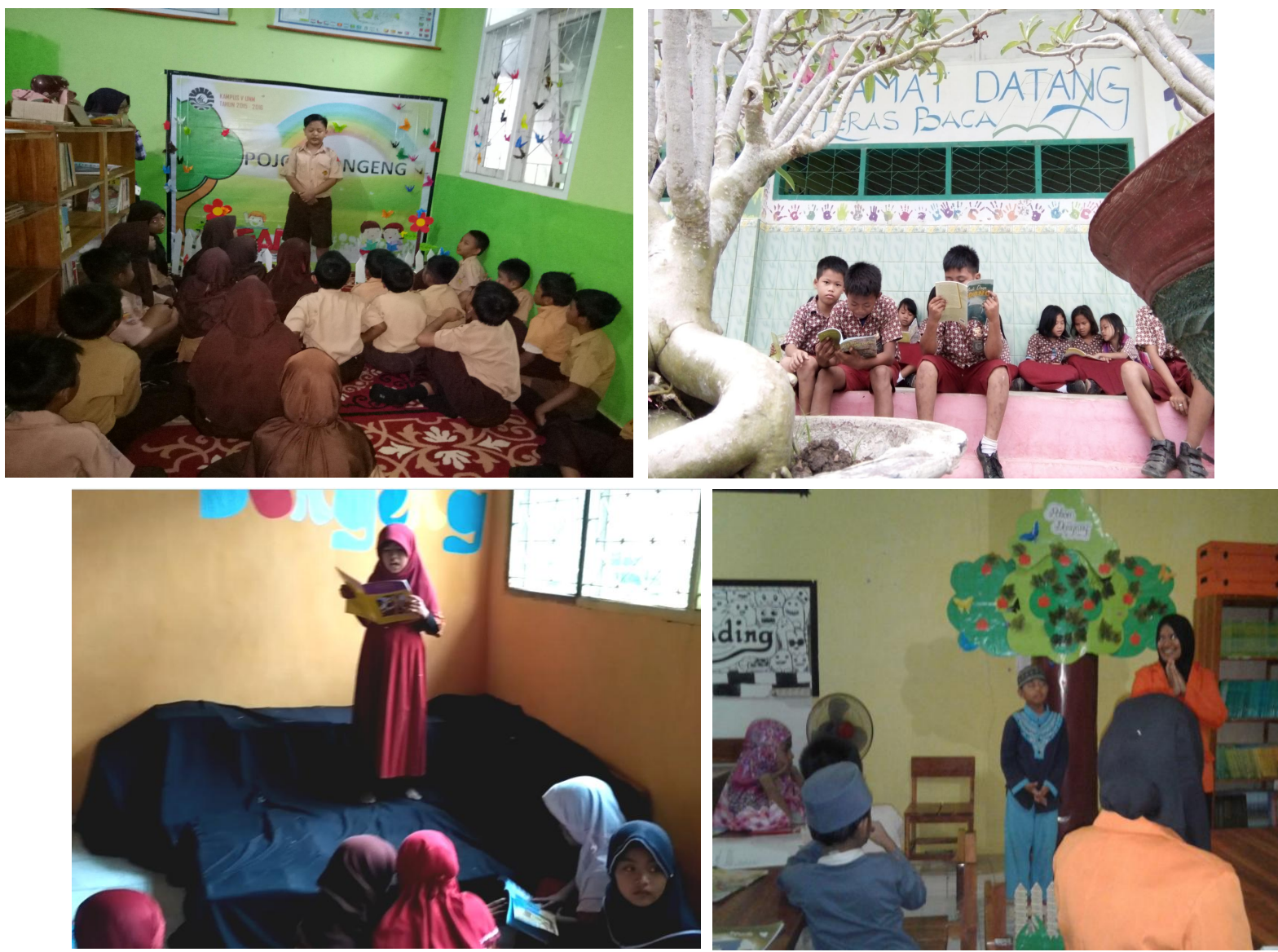

Program untuk memacu siswa semakin rajin membaca dan merasa tertantang melalui berbagai kegiatan yang beragam di SDN 79, SDN 89, SDN 85 dan SD Muhammadiyah 01 Kota Parepare

\section{Pembahasan}

Dari semua program yang telah dijalankan saat pendampingan melalui berbagai kegiatan di 6 sekolah sasaran, maka sesungguhnya telah mengembalikan fungsi perpustakaan sebagai pusat kegiatan pengembangan literasi siswa, sekaligus perpustakaan sebagai motor penggerak gerakan literasi sekolah. Tidak dapat dipungkiri bahwa gerakan literasi sekolah yang telah berusia lebih dari dua tahun masih dimaknai oleh sebagian guru dan kepala sekolah sebagai gerakan mewajibkan membaca 15 menit sebelum pembelajaran semata, namun lupa membangkitkan gairah memanfaatkan perpustakaan sebagaimana mestinya. Hal ini terjadi pula di sekolahsekolah yang fasilitas perpustakaannya terbilang lengkap.

Selain telah mengoptimalkan fungsi perpustakaan, program-program yang telah dijalankan tersebut mampu menjadi inspirasi para guru dan kepala sekolah di 6 sekolah sasaran untuk terus mengembangkannya. Ini yang dimaksudkan dengan program pemberdayaan untuk mengembangkan kompetensi sumber daya manusia pengelola perpustakaan di sekolah dasar sasaran. Pendampingan ini memang sengaja tidak memberikan program khusus untuk melatih atau memberi workshop tentang pengelolaan perpustakaan kepada 6 sekolah sasaran. Namun penadampingan ini memberikan inspirasi berupa ide-ide kreatif dan solutif untuk mengembangkan perpustakaan sambil berusaha menggerakkan kepala sekolah, guru, staf sekolah dan para siswa untuk bersamasama melakukan aksi nyata guna membangun budaya membaca siswa. Tanpa mengadakan pelatihan, workshop dan sejenisnya para guru ikut belajar bersama dalam hal mengelola, merencanakan dan melaksanakan programprogram untuk mengembangkan perpustakaan sekolah.

Dengan demikian, berdasarkan urain di atas maka tiga problem utama yaitu tata 
kelola perpustakaan, sumber daya manusia pengelolanya dan program-program pemanfaatan perpustakaan telah teratasi. Namun demikian tidak bisa hanya berhenti di situ saja, harus ada tindak lanjut. Kini giliran sekolah yang harus merawat bahkan mengembangkannya lebih lanjut. Jika pihak sekolah, terutama kepala sekolah dan para guru, benar-benar telah terinspirasi, maka semua yang telah dibangun saat penampingan ini seharusnya menjadi role model bagi pengembangan perpustakaan sekolah mereka kedepannya.

\section{KESIMPULAN \& SARAN}

Persoalan rendahnya budaya membaca dan rendahnya kemampuan literasi siswa tidak perlu diratapi apalagi sibuk mencari pihak yang bersalah. Jalan yang terbaik adalah masing-masing komponen bangsa Indonesia menjalankan perannya masing-masing dan memberikan solusi nyata untuk mengatasi akar permasalahan tersebut. Program Studi Pendidikan Guru Sekolah Dasar Universitas Negeri Makassar sebagai salah satu lembaga pendidik tenaga kependidikan (LPTK) jenjang sekolah dasar telah menjalankan peran nyata. Selain memberikan bekal kompetensi mengelola perpustakaan bagi mahasiswa calon guru sekolah dasar, melalui Program Pengabdian berupa Pendampingan Optimalisasi Fungsi Perpustakaan Untuk Menumbuhkan budaya baca Dan Kemampuan Literasi Siswa Sekolah Dasar di Kota Parepare telah berusaha memberikan solusi pada permasalahan-permasalahan di beberapa sekolah dasar di Kota Parepare terkait budaya membaca dan kemampuan literasi siswa. Melalui kerja bersama, program-program yang telah dijalankan melalui kegiatan penampingan ini telah memberikan solusi pada persoalan mendasar pada: 1) tata kelola perpustakaan, 2) peningkatan kompetensi sumber daya manusia pengelolanya dan 3) pemberdayaan program pemanfaatan perpustakaan di sekolah dasar untuk mensukseskan gerakan literasi sekolah.

$$
\text { Berdasarkan hasil kegiatan }
$$
pendampingan ini maka dapat disarankan bahwa adalah proyek ini bisa menjadi role model bagi semua pihak yang terkait dengan pengembangan perpustakaan sekolah dasar. Model dan tahapan implementasinya bisa dicoba untuk mengatasi permasalahan serupa di sekolah-sekolah lain di berbagai jenjang. Sebab dilapangan masih banyak sekolahsekolah yang masih membutuhkan uluran tangan menghadapi problematika mereka dalam upaya menumbuhkan budaya membaca dan kemampuan literasi siswa.

\section{DAFTAR PUSTAKA}

CCSU. 2016. World's Most Literate Nations, diakses

http://www.ccsu.edu/wmln/rank.html (diakses pada 20/09/2017)

OECD.2016. PISA 2015 Result in Focus, diakses

https://www.oecd.org/pisa/pisa-2015results-in-focus.pdf (diakses 20/09/2017)

Kemdikbud, 2016. Panduan Gerakan Literasi Sekolah di Sekolah Dasar. Jakarta: Dirjen Dikdasmen.

Kompas, 22/03/2017. Menurut Mendikbud

Budaya Baca Indonesia Tertinggal

Empat Tahun, diakses di http://nasional.kompas.com/read/2017/0 3/22/19073791/menurut.mendikbud.bud aya.baca.indonesia.tertinggal.empat.tahu n (diakses 21/09/2017)

Krismanto, Wawan. 2017. Kesiapan Sekolah Dasar di Kota Parepare Dalam Mengimplementasikan Gerakan Literasi sekolah. Paper Perkuliahan Prodi PGSD UNM. Belum dipublikasikan.

Sutarno, NS. 2003. Perpustakaan dan Masyarakat. Jakarta: Yayasan Obor Indonesia. 